\title{
Revisiting Namibian magmatism with Rhyolite-MELTS and the Magma Chamber Simulator
}

\author{
Paula AntoshechKinA ${ }^{1}$, Amy Riches ${ }^{2}$, AleXANDER \\ POPOV $^{1}$, PAUL ASIMOW $^{1}$ \\ ${ }^{1}$ California Institute of Technology, Pasadena, CA, USA \\ ${ }^{2}$ Department of Earth Sciences, Durham University, Durham, \\ DH1 3LE, UK
}

Modeling the early Cretaceous tholeiitic suite of picriteto-rhyolite dykes from the Spitzkoppe region of Namibia (Thompson et al., 2007), was the original motivation for adding isenthalpic assimilation and fractional crystallization to the alphaMELTS software (then called Adiabat_1ph; Smith $\&$ Asimow, 2015). For most measured major and trace elements, observed data from the dyke swarm fell between between trends modeled with (p)MELTS for (a) closedsystem fractional crystallization, dominated by conductive heat loss, and (b) heat-balanced assimilation and fractional crysallization, with local granitic crust as the contaminant. Developed since, the Magma Chamber Simulator of Bohrson et al. (2014) is the perfect tool for exploring the model space between these two end-member scenarios, especially now that trace elements and isotopes can be simultaneously calculated (Heinonen et al., submitted).

The rhyolite-MELTS model of Ghiorso \& Gualda (2015; GG15) includes the $\mathrm{CO}_{2}$ vapor phase of Duan \& Zhang (2006), multiple $\mathrm{CO}_{2}$-bearing species in the silicate liquid model, and several pure carbonate and calc-silicate solid phases. We have adapted the carbonate solid solution model of Franzolin et al. (2011) to the rhyolite-MELTS and pMELTS framework, adjusting end-member properties to maintain internal consistency with the Berman (1988) / MELTS database. Routines to detect the solvus temperature within (1) synthetic data generated in Perple_X and (2) the MELTS-coded trial carbonate model were developed. Residuals in solvus temperatures as a function of pressure and composition were minimized by varying dolomite and ankerite order parameters with a genetic algorithm. Here, we use the combined rhyolite-MELTS and carbonate solution model to test whether ankerite carbonatite intrusions and nepheline syenites from Swartbooisdrif, Namibia are related, and the extent to which they have recrystallized post-intrusion (Thompson et al. 2002; Drüppel et al. 2004). 